\title{
FORUM
}

\section{Interaction Between Ants and Plants Bearing Extrafloral Nectaries in Cerrado Vegetation}

\author{
Paulo S. Oliveira ${ }^{1}$ and Marcio R. Pie ${ }^{1}$ \\ ${ }^{1}$ Departamento de Zoologia, Universidade Estadual de Campinas, \\ Caixa postal 6109, 13083-970, Campinas SP, Brasil. \\ An. Soc. Entomol. Brasil 27(2): 161-176 (1998) \\ Interações entre Formigas e Plantas com Nectários Extraflorais \\ na Vegetação do Cerrado
}

\begin{abstract}
RESUMO - Nectários extraflorais (NEFs) são glândulas de néctar não relacionadas com o processo de polinização da planta e que podem ocorrer virtualmente em todas as estruturas vegetativas e reprodutivas de angiospermas. Estudos recentes revelaram que NEFs ocorrem em diversas espécies de arbustos e árvores dos cerrados brasileiros. Plantas portadores destas glândulas são visitadas de dia e de noite por diversas espécies de formigas nectarívoras do cerrado. Nesta revisão apresentamos os dados obtidos nos últimos 15 anos sobre a interação entre formigas e plantas com NEFs em vegetação de cerrado. Estudos experimentais no campo indicam que as formigas visitantes de NEFs podem predar ou injuriar insetos herbívoros que encontram sobre as plantas, reduzindo significativamente as taxas de herbivoria sobre as folhas, botões ou flores. Em resposta, algumas espécies de herbívoros desenvolveram vários mecanismos para evitar o ataque das formigas sobre suas plantas hospedeiras. Os benefícios oferecidos às plantas pelas formigas visitantes, entretanto, podem variar com a agressividade da espécie de formiga, com as estratégias defensivas apresentadas pelos insetos herbívoros, bem como com a espécie de planta. Os resultados obtidos para diferentes espécies de plantas de cerrado são discutidos, indicando áreas promissoras para estudos experimentais futuros.
\end{abstract}

PALAVRAS-CHAVE: Insecta, Hymenoptera, herbivoria, mutualismo, predação.

ABSTRACT - Extrafloral nectaries (EFNs) are nectar-secreting glands not directly involved with pollination which may occur on virtually all above-ground plant parts of angiosperms. Recent studies revealed that such glands are widely distributed amongst the woody flora of the Brazilian cerrados. Plants bearing EFNs are visited day and night by a diverse assemblage of nectarivorous ants. In this review we present the data gathered during the past 15 years on the interaction between ants and EFN-bearing plants in cerrado vegetation. Field experiments indicate that ants visiting EFNs may prey or attack insect herbivores on the plant foliage, significantly reducing herbivore damage to leaves, buds or flowers. As a response, some herbivore species have developed an array of mechanisms to circumvent the ants' deterring capacities on their host 
plants. Ant-derived benefits to plants, however, may vary with the species of visiting ant, with the defensive tactics of the associated herbivores, as well as with the plant species. We discuss the results obtained for different cerrado plant species, and suggest some promising topics for future experimental investigation.

KEY WORDS: Insecta, Hymenoptera, herbivory, mutualism, predation.

"The hypothesis of intimate mutualistic relations between ants and the higher plants is one of those fascinating constructions in which certain gifted and imaginative botanists have rivalled the inventors of the mimicry hypothesis in the zoological field. Both of these constructions have been treated as facts of the utmost value in supporting a still more general hypothesis - that of natural selection, and both, after having been carried to extremes by their respective adherents, are now facing the reaction that is overtaking Neodarwinism. Authors like Fritz Müller, Schimper, Huth, Delpino, Beccari and Heim have marshalled a formidable array of $o b$ servations in favor of the view that many plants develop elaborate structures to be used as lodgings by certain pugnacious ants or even furnish these insects with exquisite food substances, and in return for these services are protected by their tenants from the leafcutting ants or from other leaf-destroying animals. These observations are now being subjected to critical revision by authors like Rettig and H. von Ihering, whose attitude toward the whole suject is avowedly skeptical and reactionary. It behooves us therefore to examine both sides of the argument and, if possible, to adopt a position which will favor and not forestall further investigation."

(William M. Wheeler, 1910)

The natural history of ant-plant associations has attracted the attention of biologists around the world for nearly two centuries. During this time it became evident that ants and plants can affect each other's lives in diverse and complex ways. Although the sug- gestion of mutualistic interactions between ants and plants is present in the classic works of naturalists such as Belt (1874), Delpino (1875), and Trelease (1881), at that time the supporting evidence was based mostly on detailed anatomical and/or behavioral observations rather than experimental demonstration. In fact, as shown in the opening paragraph quoted from Wheeler's book on ants (see above), this theme stimulated a considerable amount of debate among early naturalists. Despite the wide taxonomic and geographical distributions of myrmecophilous plants (Bequart 1922, Wheeler \& Bequart 1929, Wheeler 1942), and their intrinsic biological importance, it was not until about three decades ago that the pioneering field studies of Janzen (1966, 1967, 1969) provoked a burst of research on ant-plant interactions by ecologists around the world. Since then many excellent experimental field studies have been conducted, embracing a wide variety of antplant systems from many kinds of environments (reviewed by Davidson \& McKey 1993).

With the exception perhaps of the socalled harvester ants which store and consume seeds (Beattie 1995), and the leaf-cutting ants which may severely defoliate both native and cultivated plants (Vander Meer et al. 1990), many ant taxa are known to maintain facultative or obligate mutualisms with many species of angiosperms from different families (see Bentley 1977, Buckley 1982, Koptur 1992, Hölldobler \& Wilson 1990, Schupp \& Feener 1991, Davidson \& McKey 1993). Experimental field studies have shown that plants may benefit from interacting with ants 
in basically five ways (after Beattie 1985): (1) the ants protect the plant against herbivores; (2) the ants promote the growth and survival of the host plant by pruning foliage of neighboring plants; (3) the ants feed the plant with essential nutrients; (4) the ants disperse seeds and fruits; (5) the ants pollinate the plant. In exchange for these services, ant-associated plants usually produce two main rewards for the ants - nest site and/or food.

Research on ant-plant interactions has developed enormously in the past decades, and the recent literature is rich in studies dealing with a diversity of aspects underlying such associations both in temperate and tropical habitats. The current state of the knowledge in this field can be assessed in the excellent reviews by Beattie (1985), Jolivet (1986), Hölldobler \& Wilson (1990), Koptur (1992) and Davidson \& McKey (1993).

In the present paper we are mostly concerned with the facultative associations involving ants and plants bearing extrafloral nectaries, and their effects on the associated insect herbivores. We will provide a review of the data gathered during the past fifteen years in the cerrado vegetation of Brazil, and suggest some promising topics for future research in the area.

\section{The Taxonomic Distribution and Abun- dance of Extrafloral Nectaries in Cerrado Vegetation}

Extrafloral nectaries are nectar-secreting organs not directly involved in pollination, although they may occur near the reproductive parts of the plant (Bentley 1977). Such glands are extremely variable morphologically and anatomically, being found on virtually all above-ground plant parts such as the leaf blade, petiole, rachis, stipules, stem, bracts, sepals, petals, fruits, and cotyledons (Bentley 1977, Elias 1983, Oliveira \& LeitãoFilho 1987, Koptur 1992, Morellato \& Oliveira, 1994). Chemical analyses of the extrafloral nectar secreted by different plant taxa have revealed that the aqueous solution may contain sugars, amino acids, proteins, lipids, and vestigial amounts of other organic compounds (Bentley 1977, Baker \& Baker 1975, 1983).

Extrafloral nectaries are widely distributed among the angiosperms of both tropical and temperate regions, although they are more commonly found in the flora of tropical areas. Quantitative floristic surveys from nine different cerrado areas in the States of São Paulo (Oliveira \& Leitão-Filho 1987) and Mato Grosso (Oliveira \& Oliveira-Filho 1991) showed that EFNs are particularly common amongst the woody flora (shrubs and trees) of this vegetation type (Table 1). A total of 44 EFN-bearing species from 17 families were sampled in the cerrados of São Paulo and Mato Grosso. The plant families most frequently having EFNs are the Mimosaceae (7 species), Bignoniaceae (6 species) and Vochysiaceae (5 species). Nectaries associated with vegetative parts such as leaves and stem were much more common (41 of 44) than those located near the bud or flower ( 7 of 44 ; see Table 1).

Data on proportion and abundance of plant species bearing EFNs in the woody flora of the nine surveyed cerrado areas of São Paulo and Mato Grosso are summarized in Table 2. EFNs were present in $15-22 \%$ of the species sampled in the cerrado areas of São Paulo, with local abundances ranging from 8 to $20 \%$ of the woody individuals (Oliveira \& Leitão-Filho 1987). In Mato Grosso, nectariferous species comprised $21-26 \%$ of the sampled flora and accounted for $22-31 \%$ of the shrubs and trees recorded (Oliveira \& Oliveira-Filho 1991). In general the values obtained in cerrado areas (Table 2) are higher that those from temperate habitats, and tend to support the contention that EFNs are more common in tropical than in temperate floras (see also Bentley 1977, Keeler 1979a, b, 1980, 1981a, b, Pemberton 1988, Schupp \& Feener 1991, Coley \& Aide 1991, Morellato \& Oliveira 1991, Koptur 1992).

\section{Ants, Extrafloral Nectaries, and the Protectionist Hypothesis}

Ants outnumber all other terrestrial ani- 
Table 1. Plant species bearing extrafloral nectaries in cerrado vegetation. Data are based on surveys of woody plants conducted by Oliveira \& Leitão-Filho (1987) in five cerrado areas in the state of São Paulo, and by Oliveira \& Oliveira-Filho (1991) in four areas in the state of Mato Grosso. Only shrubs and trees with a basal trunk diameter of at least $3 \mathrm{~cm}$ were included in the surveys.

\begin{tabular}{|c|c|c|c|}
\hline Plant species & Site of nectary & Plant species & of nectary \\
\hline \multicolumn{4}{|l|}{ BigNONIACEAE } \\
\hline Arrabidaea brachipoda & leaf blade & MARCGRAVIACEAE & \\
\hline Cybistax antisyphillitica & leaf blade & Norantea guianensis & leaf blade \\
\hline Jacaranda cuspidifolia & leaf blade & MimosaceAe & \\
\hline Tabebuia aurea & leaf blade & Anadenantera falcata & rachis \\
\hline Tabebuia caraiba & leaf blade & Enterolobium gummiferum & rachis \\
\hline Tabebuia ochracea & leaf blade & Inga uruguensis & rachis \\
\hline BOMBACACEAE & & Inga heterophylla & rachis \\
\hline Eriotheca gracilipes & petiole & Mimosa xanthocentra & rachis \\
\hline CAESALPINACEAE & & Plathymenia reticulata & rachis \\
\hline Bauhinia rufa & intrastipular trichomes & Stryphnodendron adstringens & rachis \\
\hline Cassia rugosa & rachis & Stryphnodendron obovatum & rachis \\
\hline Cassia speciosa & rachis & Stryphnodendron polyphyllum & rachis \\
\hline CARYoCARACEAE & & MyrsinaCEAE & \\
\hline Caryocar brasiliense & calyx & Rapanea guianensis & leaf blade \\
\hline Chrysobalanaceae & & Rapanea lancifolia & leaf blade \\
\hline Hirtella gracilipes & leaf blade & OChNACEAE & \\
\hline Hirtella hoehney & leaf blade & Ouratea castanaefolia & stipules \\
\hline Licania humilis & leaf blade & Ouratea hexasperma & stipules \\
\hline COMBRETACEAE & & Ouratea spectabilis & stipules \\
\hline Terminalia argentea & petiole & ROSACEAE & \\
\hline Terminalia brasiliensis & petiole & Prunus sellowii & leaf blade \\
\hline Terminalia fagifolia & petiole & RUBIACEAE & \\
\hline Terminalia subsericea & petiole & Tocoyena brasiliensis & calyx \\
\hline EBENACEAE & & Tocoyena formosa & calyx \\
\hline Diospyrus coccolobifolia & leaf blade & VERBENACEAE & \\
\hline EUPHORBIACEAE & & Aegiphila lhotzkiana & leaf blade \\
\hline Hieronyma alchorneoides & leaf blade & Aegiphila sellowiana & LEAF BLADE \\
\hline Richeria grandis & petiole & VOCHYSIACEAE & \\
\hline LYTHRACEAE & & Callisthene fasciculata & stem \\
\hline Lafoensia paccari & leaf blade & Qualea dichotoma & stem, pedicel \\
\hline MALPIGHIACEAE & & Qualea grandiflora & stem, pedicel \\
\hline Heteropteris acutifolia & leaf blade & Qualea multiflora & stem, pedicel \\
\hline Heteropteris byrsonimifolia & leaf blade & Qualea parviflora & stem, pedicel \\
\hline
\end{tabular}

mals (Wheeler 1910) and the colonies of some species may contain over 20 million individuals (Wilson 1971). The dominance of ants is particularly conspicuous in tropical habitats such as the Amazonian rain forests, where these insects may account for nearly $70 \%$ of the individual arthropods found on the forest canopy (Tobin 1991). The diversity of arboreal ants in tropical localities is equally impressive - a single tree in a Peruvian Ama- 
Table 2. Occurrence and abundance of woody plants with extrafloral nectaries in cerrado areas of São Paulo and Mato Grosso.

\begin{tabular}{lcccl}
\hline Area & $\begin{array}{c}\text { No. of species } \\
\text { sampled }\end{array}$ & $\begin{array}{c}\text { Percentage with } \\
\text { EPNs sampled }\end{array}$ & \multicolumn{2}{c}{$\begin{array}{c}\text { Percent cover of } \\
\text { plants with EFNs }\end{array}$} \\
\hline $\begin{array}{l}\text { São Paulo } \\
\text { Itirapina }\end{array}$ & 117 & 15.4 & 17.5 & $(879 / 5029)$ \\
São Simão & 65 & 20.0 & 18.6 & $(426 / 2295)$ \\
Mogi-Guaçu & 104 & 20.2 & 20.3 & $(1920 / 9435)$ \\
Moji-Mirim & 103 & 16.5 & 15.1 & $(479 / 3167)$ \\
Luís Antonio & 64 & 21.9 & 7.6 & $(262 / 3428)$ \\
Mato Grosso & & 23.4 & 28.1 & $(157 / 559)$ \\
Cerrado site 1 & 64 & 25.5 & 31.2 & $(74 / 237)$ \\
Cerrado site 2 & 47 & 20.6 & 27.6 & $(421 / 1524)$ \\
Cerrado site 3 & 68 & 23.3 & 21.6 & $(39 / 181)$ \\
Cerrado site 4 & 30 & &
\end{tabular}

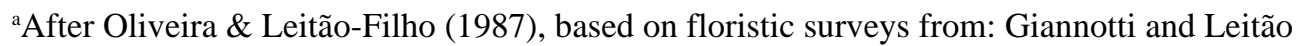
Filho (1979) (Itirapina); UNICAMP's Graduate Program in Ecology (São Simão); Gibbs et al. (1983) (Mogi-Guaçu); Toledo Filho et al. (1984) (Moji-Mirim); Toledo Filho (1984) (Luís Antonio).

${ }^{\mathrm{b}}$ After Oliveira \& Oliveira-Filho (1991).

zon forest may host 43 ant species, which is comparable to the ant fauna occurring in all of the British Isles (Wilson 1987). Such a remarkable dominance of ants on plant foliage in tropical habitats may suggest that a large part of their diets is comprised by plant-derived food resources, as for example plant nectar (Tobin 1991, Rico-Gray 1993). In fact, as reported above, plants bearing extrafloral nectaries are very common in tropical environments, and although they attract a variety of nectar-feeding insects, ants are by far the most frequent visitors of these glands (Oliveira \& Brandão 1991).

Although the controversy on the adaptive significance of extrafloral nectaries (hereafter EFNs) exists for over a century, numerous experimental field studies have provided strong evidence supporting the so-called "protectionist hypothesis" (Brown 1960, Bentley 1977). According to this view, ant visitation to EFNs is beneficial to the plant because the ants' predatory and/or aggressive behavior toward herbivores reduces significantly the damage caused to the plant by the latter. In fact, during the past few years ants visiting EFNs have been demonstrated to increase plant fitness by deterring leaf herbivores (Koptur 1979, Stephenson 1982, Smiley 1985), flower herbivores (Schemske 1980, Horvitz \& Schemske 1984, Rico-Gray \& Thien 1989), and seed predators (Inouye \& Taylor 1979, Picket \& Clark 1979). Protection by ants, however, is not universal and there are also studies showing that ants may not benefit EFN-bearing plants (O'Dowd \& Catchpole 1983, Heads \& Lawton 1984, Whalen \& Mackay 1988, Rashbrook et al. 1992).

Since extrafloral nectar is a generalized food source which attracts a wide diversity of ant taxa (Oliveira \& Brandão 1991), the mutualism between the ants and the plant is usually non-specialized and of a facultative nature (Schemske 1983, Addicott 1984). Therefore the outcome of such EFN-mediated mutualistic associations may vary with factors such as time and habitat type, aggressiveness of ant associates, and the ability of herbivores to overcome ant predation (Koptur 
1992, and included references).

\section{Ant Assemblages at Extrafloral Nectaries in Cerrado Vegetation}

The ant fauna associated with EFNs has been quantitatively surveyed on three plant species typical of cerrado vegetation: Qualea grandiflora (Vochysiaceae), Caryocar brasiliense (Caryocaraceae) and Ouratea hexasperma (Ochnaceae). Table 3 summarizes the ant genera in each subfamily and the number of species per genus recorded on each of the three plant species. The subfamilies Formicinae and Myrmicinae were the best represented at EFNs. The formicine genus Camponotus presented a higher number of species visiting EFNs than the remaining genera recorded on each of the plants censused (Table 3; see also Oliveira \& Brandão 1991, Oliveira et al. 1995).

The ant censuses conducted on shrubs of Caryocar brasiliense and Ouratea hexasperma showed that the ants actively collect extrafloral nectar on the plants both day and night (Fig. 1). The species composition of the principal ant visitors, however, changes markedly from one period to the other. The diurnal ant fauna at EFNs of Caryocar is dominated by the ants Zacryptocerus pusillus (Klug), Camponotus crassus and $C$. aff. blandus, while the species Camponotus rufipes (Fabricius), C. pallescens Mayr and $C$. renggeri Emery are the most frequent nocturnal visitors (Fig. 1). A very similar pattern was observed with the principal ant visitors of the EFNs of Ouratea (Fig. 1). A detailed account of the ant faunas associated with the EFNs of Caryocar and Ouratea is given by Oliveira \& Brandão (1991) and Oliveira et al. (1995), respectively.

Different ant species frequently have distinct humidity and temperature preferences, especially in tropical habitats, which may result in the segregation of the daily foraging schedules by sympatric ant species (Levings 1983, Torres 1984). Ant species replacements at long-lasting liquid food sources (i.e., extrafloral nectar, homopteran honeydew, lepidopteran secretions) have already been reported by several authors, and its possible that such a temporal segregation of foraging activities ultimately reduces interspecific competition among the ants (Hill \& Blackmore 1980, Hölldobler 1986, Klotz 1984, Oliveira \& Brandão 1991, DeVries 1991, Oliveira et al. 1995).

\section{Ants as Anti-Herbivore Agents of Plants with Nectaries: The Evidence in Cerrado Vegetation}

Experiments with Qualea spp. (Vochysiaceae). The first attempt to test the potential of ants as anti-herbivore agents of nectary plants in cerrado vegetation was performed by Oliveira et al. (1987) with Qualea grandiflora, a tree species that bears paired EFNs along the stems, next to the insertion of leaves. The results showed that EFNs are important promoters of ant activity on $Q$. grandiflora leaves. Frequency of ant accupancy (i.e., proportion of plants being visited by ants) and mean number of ants per plant were shown to be much higher on $Q$. grandiflora than on neighbouring plants without EFNs. Moreover, using live workers of the termite Armitermes euamignathus (Termitidae) as baits for ants on experimental plant pairs, Oliveira et al. (1987) demonstrated that: (1) ant visitors to EFNs do attack and remove the termites from leaves of $Q$. grandiflora; (2) increased ant densities on $Q$. grandiflora result in many more termites being attacked by foraging ants on this species than on neighbouring plants lacking EFNs; (3) out of 12 ant species recorded attacking the termites, three common and aggressive Camponotus species (C. rufipes, $C$. crassus and $C$. aff. blandus) clearly showed the greatest potential for herbivore deterrence, together accounting for $87 \%$ of the termites attacked on leaves of $Q$. grandiflora. Although these results strongly suggest that visiting ants to EFNs would deter potential herbivores in the cerrado, they were based on experiments with live termites used as simulated herbivores. Therefore additional experiments were 


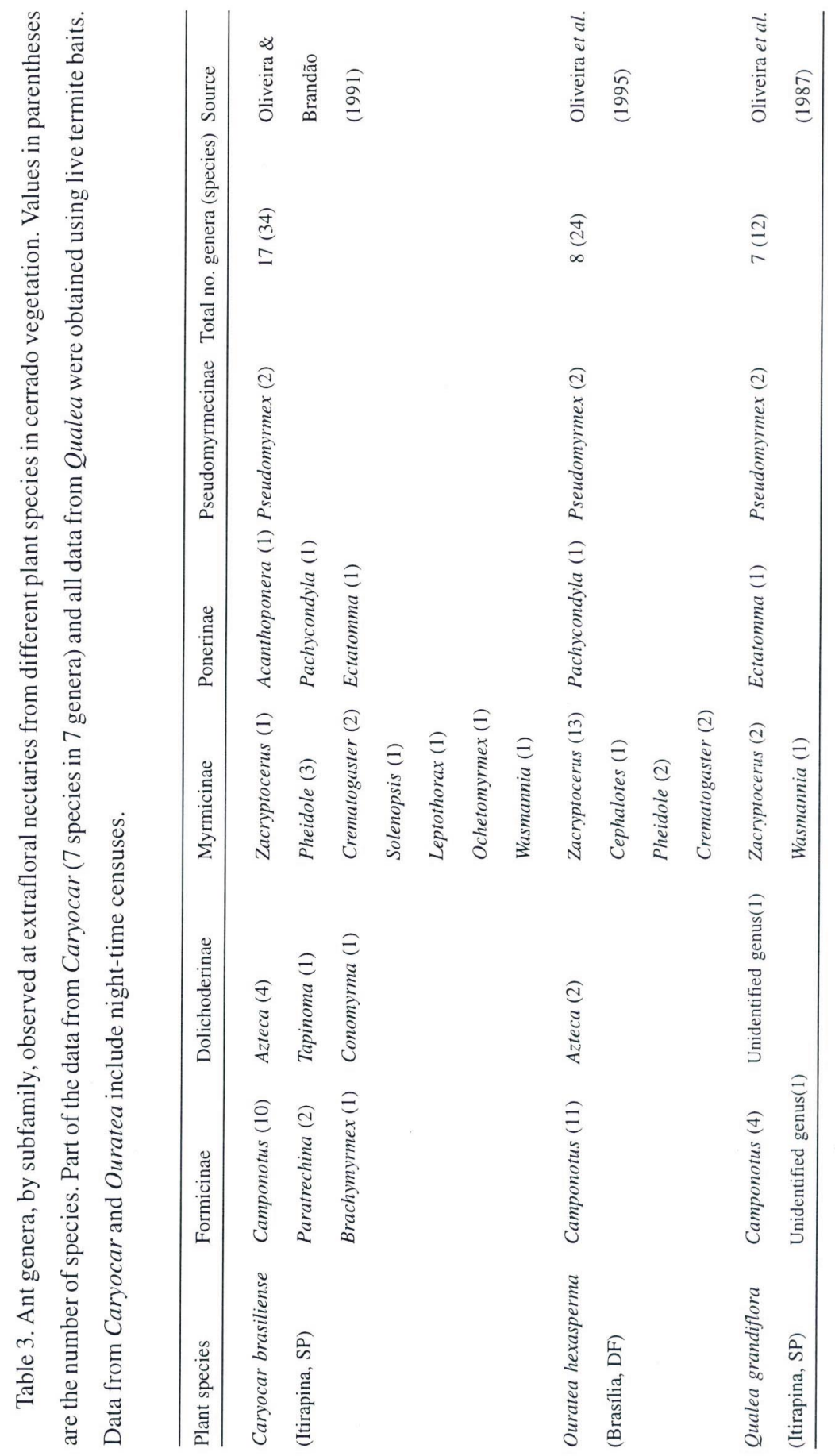


needed in order to demonstrate that visitation by ants would in fact reduce herbivore damage to $Q$. grandiflora. A second field experiment with trees of $Q$. grandiflora was carried out to test this hypothesis.

Costa et al. (1992) compared the levels of herbivore damage to leaves of 15 pairs of experimental Q. grandiflora trees. An experimental plant pair consisted of two neighbouring $Q$. grandiflora trees, each being randomly assigned as either a control or treatment plant. Ants had free access to control plants but were impeded from climbing onto treatment $Q$. grandiflora trees by the application of a sticky barrier to the base of their trunks $(15 \mathrm{~cm}$ above ground). Results showed that, after two months of exposure to herbivores, ant-excluded trees suffered significantly higher levels of leaf damage by Compsolechia caterpillars (Lepidoptera: Gelechiidae) than ant-visited control plants (Costa et al. 1992). Field observations indicated that foraging ants visiting Qualea's EFNs did in fact attack the caterpillars on the leaves of control plants.

It remained to Del-Claro et al. (1996) to unequivocally demonstrate that ant visitation to Qualea can increase plant fitness in the cerrado by limiting herbivore damage to leaves, buds and flowers of $Q$. multiflora. These authors showed that herbivore deterrence by visiting ants increases in $40 \%$ the fruit set of control $Q$. multiflora trees as compared to ant-excluded trees.

\section{Experiments with Caryocar brasiliense} (Caryocaraceae). Caryocar brasiliense is a typical plant of the Brazilian cerrados, locally known as "pequizeiro" through most of its distribution. The plant has EFNs on the outer surface of the bud sepals and at the margins of shoot tips (Oliveira \& Leitão-Filho 1987). Systematic censuses of the associated ant fauna (see above) revealed that the plant is actively visited by ants both day and night (Oliveira \& Brandão 1991). Results from a 3-year study in the cerrado area of Itirapina (São Paulo) revealed that ant visitation to EFNs of $C$. brasiliense can markedly affect the infestation levels by most of the principal insect herbivores of the plant (Oliveira 1997).

Shrubs of $C$. brasiliense are more frequently visited by ants than neighbouring plants without EFNs. Moreover, visiting ants attack and remove live insects which they find on the plant's foliage, especially near the EFNs. The results of the ant-exclusion experiments with Caryocar shrubs are summarized below for five principal associated herbivores (see also Oliveira 1997):

Eunica bechina Talbot (Lepidoptera: Nymphalidae) - eggs are laid singly on young leaves and shoot tips, and the larvae feed preferentially on young leaves (Oliveira \& Freitas 1991; Freitas \& Oliveira 1992). Foraging ants do not destroy Eunica eggs, but may prey and remove the caterpillars from the plant. Antexcluded plants are significantly more infested by eggs and larvae of E. bechina, and adult butterflies visually avoid ovipositing on plants with high levels of ant visitation (Freitas \& Oliveira 1996);

Edessa rufomarginata (De Geer) (Hemiptera: Pentatomidae) - adults mate on the plant, and egg batches consist of 6-14 eggs. Nymphs and adults feed on buds and fruits. Foraging ants prey on nymphs, and disturb nymphs and adults when these are feeding or walking on the plant. Plants without ants have increased numbers of hemipteran eggs;

Prodiplosis floricola (Felt) (Diptera: Cecidomyiidae) - females oviposit on developing buds which are destroyed by the larvae. High ant densities near the EFNs disturb ovipositing flies. Ant-excluded inflorescences have a significantly greater proportion of buds infested by the dipterans as compared to inflorescences with free ant access;

Unidentified stem-galling wasp (Hymenoptera: Chalcidoidea) - wasps induce galls on the stem. Heavily attacked branches are deprived of leaves and reproductive organs. Intense ant traffic along the stem, which is the main route to the EFNs, probably disturbs ovipositing wasps. Ant-excluded plants had higher infestation levels by stem-galling wasps;

Unidentified leaf-galling wasp (Hymenoptera: Chalcidoidea) - wasps induce galls over 


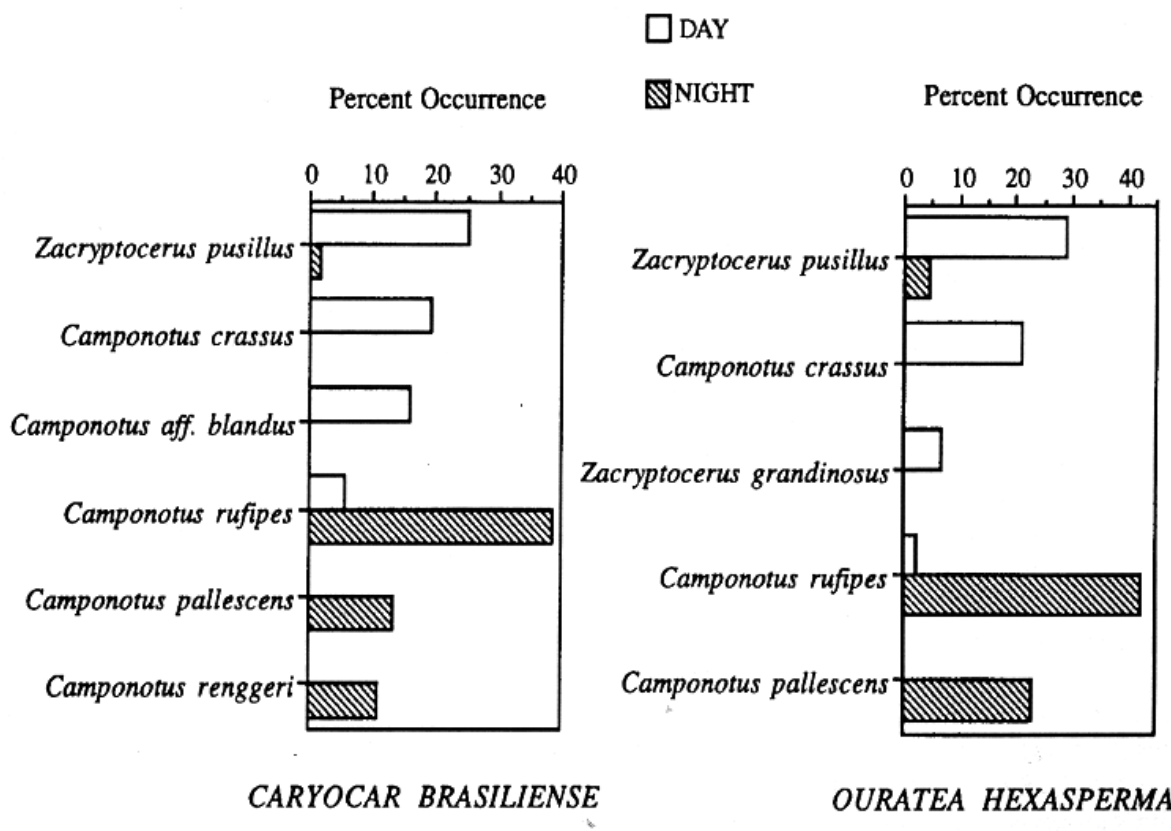

Figure 1. Daily turnover in species compositon of the principal ant visitors to the extrafloral nectaries of Caryocar brasiliense (left) in a cerrado area of Itirapina (SP), and Ouratea hexasperma (right) in a cerrado area near Brasília (DF). A total of 27 ant species were recorded during censuses on Caryocar, and 24 on Ouratea. Data are expressed as the percent occurrence of each species during diurnal and nocturnal censuses on each plant species. See also Oliveira \& Brandão (1991) and Oliveira et al. (1995).

the leaf blade. Heavily attacked leaves fall prematurely. Ants have no effect on the infestation levels by leaf-galling wasps.

The experimental study with $C$. brasiliense demonstrated that ant visitation to EFNs significantly decreases the infestation levels by four out of five of the principal herbivores associated with this cerrado plant species. However, as opposed to the findings of Del-Claro et al. (1996) with Qualea multiflora (see above), such a deterrent effect by the ants does not affect the reproductive output of $C$. brasiliense. Although flower and initial fruit production was significantly greater on antvisited than on ant-excluded shrubs of Caryocar, higher abortion rates of initial fruits by ant-visited plants resulted in similar final fruit and seed sets for both categories of ex- perimental plants (Oliveira 1997).

Contrary to Qualea multiflora trees which produce many dry 'cheap' fruits with 10 to 18 wind-dispersed seeds (Del-Claro et al. 1996), C. brasiliense shrubs produce 1 to 4 fleshy 'expensive' fruits containing 1 to 4 large vertebrate-dispersed seeds (Gottsberger $\&$ Silberbauer-Gottsberger 1983). Since cerrado soils are characteristically poor (Eiten 1972) and the lack of soil nutrients is known to negatively affect final fruit set in plants (Stephenson 1981), it is reasonable to suppose that the low fertility of cerrado soils could constrain the ability of Caryocar shrubs to provide the resources necessary for growth and development of their heavy fleshy fruits. Competition among developing fruits and subsequent abortion would therefore neutra- 
lize the initial higher production of flowers and fruits by ant-visited Caryocar shrubs as compared to ant-excluded ones (Oliveira 1997). Although this hypothesis needs further confirmation with soil-enrichment experiments (see Willson \& Price 1980), resource limitation has already been suggested to affect other ant-plant systems (Kelly 1986, Folgarait \& Davidson 1994).

Finally, although herbivore deterrence by visiting ants does not affect the reproductive output of Caryocar shrubs in the cerrado, ant visitation to EFNs may still be advantageous for the plants if (see Oliveira 1987): (1) the ants protect the plant's vegetative tissues during plant growth; (2) the plant's attractiveness to bat pollinators is increased by a large floral display (Augspurger 1980, Gribel \& Hay 1993); (3) a surplus number of hermaphroditic flowers increases male contribution to fitness through pollen donation (Willson \& Price 1977); (4) a surplus number of initial fruits and seeds allows the plant to selectively abort genetically inferior progeny (Janzen 1977).

\section{Ant Foraging on Extrafloral Nectaries and its Effects on the Behavioral Biology of Insect Herbivores}

Ants comprise an important component of the insect fauna found on the plant surface, especially on plant species producing food rewards such as extrafloral nectar (Oliveira $\&$ Brandão 1991). As we have seen, herbivore deterrence on such plants results from the ants' predatory and/or aggressive behavior near the nectar source (Bentley 1977). Phytophagous insects exploiting ant-visited plants must cope with the threat of ant predation or ant-induced injuries, and many of such herbivore species have developed an array of mechanisms to circumvent the ants' deterring capacities on their host plants (Janzen 1967, Koptur 1984, Heads \& Lawton 1985, Costa et al. 1992). One of these mechanisms involve the secretion by the insect herbivore of sweet appeasing substances which decrease the risk of ant attacks on the host plant, as for exam- ple in some ant-tended homopterans and butterfly larvae (Mallicky 1971, Atsatt 1981, Buckley 1987, Del-Claro \& Oliveira 1996).

Most experimental studies on the interaction between ants and EFN-bearing plants have focused on the protective role of the ants against the plant's associated herbivores and the consequences of such protection, if any, on the plant's reproductive output (reviewed by Koptur 1992). It is surprising that such antplant systems have rarely been studied from the herbivore's standpoint (but see Heads \& Lawton 1985). Although a few studies have already examined the effects of ant interference on butterfly biology and behavior, most of the data is descriptive rather than experimental (Brown 1981, Turner 1981, Smiley 1985, 1986).

Recent field experiments with the butterfly $E$. bechina on shrubs of $C$. brasiliense investigated how ant visitation patterns to this nectary plant can affect the behavioral biology of both immature and adult Eunica. Results can be summarized as follows (see also Freitas \& Oliveira 1992, 1996): Eunica caterpillars feed on young leaves of Caryocar and larval mortality is strongly dependent on the level of ant visitation to the host plant. Larvae feeding on highly visited plants have an increased risk of ant predation. Vulnerability to ant predation, however, decreases with larval size. Stick-like frass chains constructed by the larvae at leaf margins were demonstrated to be a safe refuge against attacks by foraging ants on Caryocar. Butterfly eggs are not removed by ants, but the oviposition behavior of Eunica is strongly affected by the level ant visitation to the plants. Eunica females visually avoid ovipositing on highly visited plant locations - branches with artificial rubber ants were less infested by butterfly eggs than control branches with rubber circles. These data show that ant visitation patterns on Caryocar shrubs strongly affect the behavior of both immature and adult Eunica, and provide the first demonstration that egg-laying decisions by a nonmyrmecophilous butterfly can be influenced by ant presence on the host plant (see also 
Attsat 1981, Pierce \& Elgar 1985, Freitas \& Oliveira 1992, 1996, Oliveira 1997).

\section{Concluding Remarks}

Plants bearing extrafloral nectaries are widespread amongst the woody flora of Brazilian cerrado vegetation. A diverse assemblage of nectar-gathering ant species visit these glands both day and night and may act as anti-herbivore agents, significantly reducing herbivore damage on vegetative as well as on reproductive plant parts. The outcome of such facultative mutualistic associations, however, may vary both geographically and temporally and may be also conditioned by diverse factors such as the species of visiting ant and the escape tactics of the associated herbivore species (Koptur 1992, and included references). Future research on ants and EFNbearing plants in cerrado vegetation should take into account other factors that may possibly also affect ant-derived benefits to the plants . For example, the degree to which herbivore deterrence by ants can be translated into greater fecundity (i.e., increased number of fruits and seeds) by a given nectary plant species may vary with traits such as the plant's habit (shrub versus tree) and fruit type (dry versus fleshy fruits), as well as with soil nutrients. Although there is evidence suggesting that such factors may condition the outcome of certain ant-plant systems in the cerrado (Del-Claro et al. 1996, Oliveira 1997), additional experiments are needed in order to better understand the dynamics of such mutualistic interactions in this vegetation type.

\section{Acknowledgements}

We are most grateful to Drs. Antônio R. Panizzi and Evaldo Vilela for the invitation to write this review. Research on ant-plant interactions over the past years was supported by a series of grants to P. S. Oliveira from the CNPq, FAPESP and FAEP/UNICAMP. M. R. Pie was supported by a graduate fellowship from CAPES.

\section{References Cited}

Addicott, J.F. 1984. Mutualistic interactions in populations and community processes, p. 438-455. In P.W. Price, C.N. Slobodchikoff \& W.S. Gaud (eds.), A New Ecology. New York, John Wiley \& Sons, $515 \mathrm{p}$.

Atsatt, P.R. 1981. Lycaenid butterflies and ants: selection for enemy-free space. Am. Nat. 118: 638-654.

Augspurger, C.K. 1980. Mass-flowering of a tropical shrub Hybanthus prunifolius: influence on pollinator attraction and movement. Evolution 34: 475-488.

Baker, H.G. \& I. Baker. 1975. Nectar constitution and pollinator-plant coevolution, p. 100-140. In L.E. Gilbert \& P.H. Raven (eds.), Animal and plant coevolution. Austin, University of Texas Press, 263 p.

Baker, H.G. \& I. Baker. 1983. A brief historical review of the chemistry of floral nectar. p. 126-152. In B. Bentley, B. \& T. Elias (eds.), The biology of nectaries. New York. Columbia University Press, $259 \mathrm{p}$.

Beattie, A.J. 1985. The Evolutionary Ecology Ant-Plant Mutualisms. Cambridge, Cambridge University Press, 182p.

Belt, T. 1874. The naturalist in Nicaragua. London, John Murray, 403p.

Bentley, B.L. 1977. Extrafloral nectaries and protection by pugnacious bodyguards. Ann. Rev. Ecol. Syst. 8: 407-428.

Bequaert, J. 1922. Ants in their diverse relations to the plant world. Bull. Amer. Mus. Nat. Hist. 45: 333-621.

Brown, K.S., Jr. 1981. The biology of Heliconius and related genera. Annu. 
Rev. Entomol. 26: 427-456.

Brown, W.L., Jr. 1960. Ants, acacias and browsing mammals. Ecology 41: 587592.

Buckley, R. 1982. Ant-plant interactions: a world review, p. 111-141. In R. Buckley (ed.), Ant-Plant Interactions in Australia. The Netherlands, Dr. W. Junk, The Hague, 162 p.

Buckley, R. 1987. Interactions involving plants, Homoptera, and ants. Annu. Rev. Ecol. Syst. 18: 111-138.

Coley, P.D. \& M.A. Aide.1991. Comparison of herbivory and plant defenses in temperate and tropical broad-leaved forests, p. 25-49. In P.W. Price, T.M. Lewinsohn, G.W. Fernandes and W.W. Benson (eds.), Evolutionary ecology of plant-animal interactions: tropical and temperate comparisons. New York, John Wiley \& Sons, 639 p.

Costa, F.M.C.B., A.T. Oliveira-Filho \& P.S. Oliveira. 1992 The role of extrafloral nectaries in Qualea grandiflora (Vochysiaceae) in limiting herbivory: an experiment of ant protection in cerrado vegetation. Ecol. Entomol. 17: 362-365.

Davidson, D.W. \& D. Mackey. 1993. The evolutionary ecology of symbiotic antplant relationships. J. Hymen. Res. 2: 1383.

Del-Claro, K., V. Berto \& W. Réu. 1996. Effect of herbivore deterrence by ants on the fruit set of an extrafloral nectary plant, Qualea multiflora Vochysiaceae. J. Trop. Ecol. 12: 887-889.

Del-Claro, K. \& P.S. Oliveira. 1996. Honeydew flicking by treehoppers provides cues to potential tending ants. Anim. Behav. 51: 1071-1075.
Delpino, F. 1875. Rapporti tra insetti e tra nettari estranuzali in alcune piante. Boll. della Soc. Entomol. Firenze 7: 69-90.

DeVries, P. J. 1991. Evolutionary and ecological patterns in myrmecophilous riodinid butterflies, p. 143-156. In C. R. Huxley \& D. F.Cutler (eds.), Ant-plant interactions. Oxford, Oxford University Press, $259 \mathrm{p}$.

Eiten, G. 1972. The cerrado vegetation of Brazil. Bot. Rev.38: 201-341.

Elias, T.S. 1983. Extrafloral nectaries: their structure and distribution, p. 174-203. In B.L. Bentley and T.S. Elias (eds.), The biology of nectaries. New York, Columbia University Press.

Folgarait, P.J. \& D.W. Davidson. 1994. Responses of Cecropia to experimental removal removal of Müllerian bodies. Funct. Ecol. 8: 22-28.

Freitas, A.V.L. \& P.S. Oliveira. 1992. Biology and behavior of Eunica bechina (Lepidoptera: Nymphalidae) with special reference to larval defense against ant predation. J. Res. Lepid. 31: 1-11.

Freitas, A.V.L. \& P.S. Oliveira. 1996. Ants as selective agents on herbivore biology: effects on the behaviour of a nonmyrmecophilous butterfly. J. Anim. Ecol. 65: 205-210.

Giannotti, E. \& H.F. Leitão Filho. 1979. Composição e estrutura de uma área de cerrado no Estado de São Paulo, município de Itirapiuna. Resumos do XXX Congresso Nacional de Botânica, Campo Grande, p.183.

Gibbs, P.E., H.F. Leitão Filho \& G.J. Shepherd. 1983. Floristic composition and community structure in an area of cerado in southeastern Brazil. Flora 173: 
433-449.

Gottsberger, G. \& I. SilberbauerGottsberger. 1983. Dispersal and distribution in the cerrado vegetation of Brazil. Sonderbd. naturwiss. Ver. Hamburg 7: 315-353.

Gribel, R. \& J.D. Hay. 1993. Pollination ecology of Caryocar brasiliense (Caryocaraceae) in Central Brazil cerrado vegetation. J. Trop. Ecol. 9: 199-211.

Heads, P.A. \& J.H. Lawton. 1984. Bracken, ants and extrafloral nectaries. II. The effect of ants on the insect herbivores of bracken. J. Anim. Ecol. 53: 1015-1031.

Heads, P.A. \& J.H. Lawton. 1985. Bracken, ants and extrafloral nectaries. III. How insect herbivores avoid predation. Ecol. Entomol. 10: 29-42.

Hill, M.G. \& P.J.M. Blackmore. 1980. Interactions between ants and the coccid Icerya seychellarum on Aldabra Atoll. Oecologia 45: 360-365.

Hölldobler, B. 1986. Food robbing in ants, a form of interference competition. Oecologia 69: 12-15.

Hölldobler, B. \& E.O. Wilson. 1990. The Ants. Harvard University Press, Cambridge, MA, 732 p.

Horvitz C. C. \& D.W. Schemske. 1984. Effects of ants and ant-tended herbivore on seed production of a neotropical herb. Ecology 65: 1369-1378.

Inouye, D.W. \& O.R. Taylor. 1979. A temperate region plant-ant-seed predator system: Consequences of extrafloral nectar secretion by Helianthella quinquinervis. Ecology 60: 1-7.

Janzen, D.H. 1966. Coevolution of mutualism between ants and acacias in
Central America. Evolution 20: 249-275.

Janzen, D.H. 1967. Interaction of the bull'shorn acacia Acacia cornigera $\mathrm{L}$. with an ant inhabitant Pseudomyrmex ferruginea F. Smith in Eastern Mexico. Univ. Kansas Sci. Bull. 47: 315-558.

Janzen, D.H. 1969. Allelopathy by myrmecophytes: the ant Azteca as an allelopathic agent of Cecropia. Ecology 50: $147-153$.

Janzen, D.H. 1977 A note on optimal mate selection by plants. Am. Nat. 11: 365-371.

Jolivet, P. 1986. Les fourmis et les plantes: un exemple de coévolution. Paris, Éditions Boubée, 254 p.

Keeler, K.H. 1979a. Distribution of plants with extrafloral nectaries and ants at two elevations in Jamaica. Biotropica 11: 152154.

Keeler, K.H. 1979b. Species with extrafloral nectaries in a temperate flora (Nebraska). Prairie Nat. 11: 33-37.

Keeler, K.H. 1980. The extrafloral nectaries of Ipomopea leptophylla (Convolvulaceae). Amer. J. Bot. 67: 216-222.

Keeler, K.H. 1981a. Cover of plants with extrafloral nectaries in four northern California habitats. Madrono 28: 26-29.

Keeler, K.H. 1981b. Function of Mentzelia nuda (Loasaceae) postfloral nectaries in seed defense. Amer. J. Bot. 68: 295-299.

Kelly, C.A. 1986. Extrafloral nectaries: ants, herbivores and fecundity in Cassia fasciculata. Oecologia Berlin 69: 600605.

Klotz, J.H. 1984. Diel differences in foraging in two ant species (Hymenoptera: Formicidae). J. Kansas Ent. Soc. 59: 537- 
541.

Koptur, S. 1979. Facultative mutualism between weedy vetches bearing extrafloral nectaries and weedy ants in California. Amer. J. Bot. 66: 1016-1020

Koptur, S. 1984. Experimental evidence for defense of Inga Mimosoideae saplings by ants. Ecology 65: 1787-1793.

Koptur, S. 1992. Extrafloral nectarymediated interactions between insects and plants, p. 81-129. In E. Bernays (ed.) Insect-Plant Interactions, Vol. 4. Boca Raton, CRC Press, 240 p.

Levings, S.C. 1983. Seasonal, annual, and among-site variation in the ground ant community of a deciduous tropical forest: some causes of patchy species distributions. Ecol. Monogr. 53: 435-455.

Mallicky, H. 1971. New aspects of the association between lycaenid larvae (Lycaenidae) and ants (Formicidae), Hymenoptera . J. Lepid. Soc. 24: 190202.

Morellato, L.P.C. \& P.S. Oliveira. 1991. Distribution of extrafloral nectaries in different vegetation types of Amazonian Brazil. Flora 185: 33-38.

Morellato, L.P.C. \& P.S. Oliveira. 1994. Extrafloral nectaries in the tropical tree Guarea macrophylla Meliaceae . Can. J. Bot. 72: 157-160.

O'Dowd, D.J. \& E.A. Catchpole. 1983. Ants and extrafloral nectaries: no evidence for plant protection in Helichrysum spp.-ant interactions. Oecologia 59: 191-200.

Oliveira, P.S. 1997. The ecological function of extrafloral nectaries: herbivore deterrence by visiting ants and reproductive output in Caryocar brasiliense (Caryocaraceae) . Funct. Ecol.
11: $323-330$.

Oliveira, P.S. \& C.R.F. Brandão. 1991. The ant community associated with extrafloral nectaries in Brazilian cerrados, p. 198212. In D. F. Cutler \& C. R. Huxley (eds.), Ant-Plant Interactions. Oxford, Oxford University Press, 601 p.

Oliveira, P.S. \& A.V.L. Freitas. 1991. Hostplant record for Eunica bechina magnipunctata (Nymphalidae) and observations on oviposition sites and immature biology. J. Res. Lepid. 30: 140141.

Oliveira, P.S., C. Klitzke \& E. Vieira. 1995. The ant fauna associated with the extrafloral nectaries of Ouratea hexasperma (Ochnaceae) in an area of cerrado vegetation in Central Brazil. Entomol. Month. Mag. 131: 77-82.

Oliveira, P.S. \& H.F. Leitão-Filho. 1987. Extrafloral nectaries: Their taxonomic distribution and abundance in the woody flora of cerrado vegetation in Southeast Brazil. Biotropica 19: 140-148.

Oliveira, P.S. \& A.T. Oliveira-Filho. 1991. Distribution of extrafloral nectaries in the woody flora of tropical communities in Western Brazil, p. 163-175. In P.W. Price, T.M. Lewinsohn, G.W. Fernandes and W.W. Benson (eds.), Evolutionary ecology of plant-animal interactions: tropical and temperate comparisons. New York, John Wiley \& Sons, 639 p.

Oliveira, P.S., A.F. da Silva \& A.B. Martins. 1987. Ant foraging on extrafloral nectaries of Qualea grandiflora (Vochysiaceae) in cerrado vegetation: ants as potential antiherbivore agents. Oecologia Berlin 74: 228-230

Pemberton, R.W. 1988. The abundance of plants bearing extrafloral nectaries in colorado and mojave desert communities 
of southern California. Madrono 35: 238246.

Pickett, C. H. \& W.D. Clark. 1979. The function of extrafloral nectaries in Opuntia acanthocarpa (Cactaceae) . Amer. J. Bot. 66: 618-625.

Pierce, N.E. \& M.A. Elgar. 1985. The influence of ants on host plant selection by Jalmenus evagora, a myrmecophilous lycaenid butterfly. Behav. Ecol. Sociobiol. 16: 209-222.

Rashbrook, V.K., S.G. Compton \& J.H. Lawton. 1992. Ant-herbivore interactions: reasons for the absence of benefits to a fern with foliar nectaries. Ecology 73: 2167-2174.

Rico-Gray, V. 1993. Use of plant-derived food resources by ants in the Dry Tropical Lowlands of Coastal Veracruz, Mexico. Biotropica 25: 301-315.

Rico-Gray, V. \& L.R. Thien. 1989. Antmealybug interaction decreases reproductive fitness of Schomburgkia tibicinis (Orquidaceae) in Mexico. J. Trop. Ecol. 5: 109-112.

Schemske, D.W. 1983. Limits to specialization and coevolution in plant-animal mutualisms. In Coevolution, ed. M.H. Nitecki. University of Chicago Press, Chicago, 392 p.

Schemske, D.W. 1980. The evolutionary significance of extrafloral nectar production by Costus woodsonii (Zingiberaceae) : An experimental analysis of ant protection. J. Ecol. 68: 959-967.

\section{Schupp, E.W. \& D.H. Feener. 1991.} Phylogeny, lifeform, habitat dependence of ant-defended plants in a Panamanian forest, p. 175-197. In D. F. Cutler \& C. R. Huxley (eds.), Ant-Plant Interactions.
Oxford, Oxford University Press, 601 p.

Smiley, J. T. 1985. Heliconius caterpillars mortality during establishment on plants with and without attending ants. Ecology $66,845-849$.

Smiley, J.T. 1986. Ant constancy at Passiflora extrafloral nectaries: Effects on caterpillar survival. Ecology 67: 516-521.

Stephenson, A.G. 1981. Flower and fruit abortion: proximate causes and ultimate functions. Annu. Rev. Ecol. Syst. 12: 253 279.

Stephenson, A.G. 1982. The role of the extrafloral nectaries of Catalpa speciosa in limiting herbivory and increasing fruit production. Ecology 63: 663-669.

Tobin, J.E. 1991. A neotropical, rainforest canopy, ant community: some ecological considerantions, p. 536-538. In C. R. Huxley \& D. F.Cutler (eds.), Ant-plant interactions. Oxford, Oxford University Press, $601 \mathrm{p}$.

Toledo Filho, D.V. de. 1984. Composição florística e estrutura fitosociológica da vegetação de cerrado no município de Luís Antonio (SP). Master's Thesis, Universidade Estadual de Campinas, São Paulo, 177 p.

Toledo Filho, D.V. de, H.F. Leitão Filho \& T.S. Rodrigues. 1984. Composição florística de uma área de cerrado em Moji-Mirim (SP). Arq. Inst. Florest. 38: 165-175.

Torres, J. A. 1984. Niches and coexistence of ant communities in Puerto Rico: Repeated patterns. Biotropica 16: 284295.

Trelease, W. 1881. The foliar nectar of Populus. Bot. Gaz. 6: 384-390.

Turner, J.R.G. 1981. Adaptation and 
evolution in Heliconius: a defense of neoDarwinism. Annu. Rev. Ecol. Syst. 12: 99-121.

Vander Meer, R.K., K. Jaffé \& A. Cedeno. 1990. Applied myrmecology: a world perspective. Westview Press, 741 p.

Whalen, M.A. \& D.A. Mackay. 1988. Patterns of ant and herbivore activity on five understory Euphorbiaceous saplings in submontane Papua New Guinea. Biotropica 20: 294-230

Wheeler, W.M. 1910. Ants: their structure, development and behavior. New York, Columbia University Press, 663 p.

Wheeler, W.M. 1942. Studies of neotropical ant-plants and their ants. Bull. Mus. Comp. Zool. 90: 3-262.
Wheeler, W.M. \& J.C. Bequaert. 1929. Amazonian myrmecophyes and their ants. Zool. anzeig. 82: 10-39.

Willson, M.F. \& P.W. Price. 1977. The evolution of inflorescence size in Asclepias (Asclepiadaceae) . Evolution 31: 495-511.

Willson, M.F. \& P.W. Price. 1980. Resource limitation of fruit and seed production in some Asclepias species. Can. J. Bot. 58: 2229-2230.

Wilson, E.O. 1971. The Insect Societies. Cambridge, Harvard University, Press, $548 \mathrm{p}$.

Wilson, E.O. 1987. The arboreal ant fauna of Peruvian Amazon forests: a first assessment. Biotropica 19: 245-282. 